\title{
THE CHARACTERIZATION OF HUMAN MALE-SPECIFIC 5.7 kb DNA(pKY-1) AND ITS APPLICATION TO FETAL SEX-DETERMINATION PROBE
}

\author{
Kozo NagaI, ${ }^{1}$ Satoru Kờike, ${ }^{2, *}$ Ryo Kominami, ${ }^{2, * *}$ \\ Masami Muramatsu, ${ }^{2}$ Yutaka NaKahori, ${ }^{3}$ Yasuo NaKagome, ${ }^{3}$ \\ Hiroaki Soma, ${ }^{4}$ and Isamu YANAGISAWA ${ }^{1}$ \\ Departments of ${ }^{1}$ Biochemistry, ${ }^{4}$ Obstetrics and Gynecology, Tokyo Medical College, \\ Shinjuku-ku, Tokyo 160, Japan \\ ${ }^{2}$ Department of Biochemistry, University of Tokyo School of Medicine, \\ Bunkyo-ku, Tokyo 113, Japan \\ ${ }^{3}$ Department of Congenital Abnormalities Research, National Children's Medical \\ Research Center, National Children's Hospital, Setagaya-ku, Tokyo 154, Japan
}

Summary A male-specific $5.7 \mathrm{~kb}$ DNA(pKY-1) was cloned by screening human genomic libraries. Subsequent to structural characterization, a possibility of its application for prenatal diagnosis probe was tested. The results obtained were as follows: 1) The pKY-1 was specifically hybridized with human $Y$-chromosome specific repetitive $3.5 \mathrm{~kb}$, but not with female DNA and $2.1 \mathrm{~kb}$, known to be another human Y-specific repetitive-DNA. 2) HaeIII, EcoRI and their double digestion did not produce the Y-specific $3.5 \mathrm{~kb}$ fragments from pKY-1. 3) Although the digestion of pKY-1 with BamHI liberated $0.55 \mathrm{~kb}$, ClaI clove remained $5.10 \mathrm{~kb}$ into 2.40 and $2.7 \mathrm{~kb}$ fragments, while their hybridizabilities with the $3.5 \mathrm{~kb}$ DNA were identically conserved.

These data suggest that $5.7 \mathrm{~kb}$ fragment (pKY-1) should be proposed as a member of Y-chromosome-specific repetitive DNA family in human genome. Thus, this cloned DNA will be not only a useful probe for human fetal sex-determination but also an effective tool for analysis of Y-chromosome with its structure and repetitive DNA.

Key Words male-specific $5.7 \mathrm{~kb}$ DNA, Y-specific repetitive DNA, Y-chromosome, fetal sex determination, prenatal diagnosis

Received September 12, 1989; revised version received October 12, 1989; Accepted October 24, 1989.

* Present address: Department of Biochemistry 1, Niigata University School of Medicine, 757 Ichibancho, Asahimachi-Dori, Niigata 951.

** Present address: Department of Microbiology, the Tokyo Metropolitan Institute of Medical Science, 3-18-22 Honkomagome, Bunkyo-ku, Tokyo 113.

Abbreviations: $\mathrm{kb}, 10^{3}$ bases; $\mathrm{SSC}, 0.15 \mathrm{~m}$ sodium chloride- $0.015 \mathrm{M}$ sodium citrate; SDSa, sodium $N$-lauroylsarcosinate; EDTA, ethylenediaminetetraacetic acid sodium salts. 


\section{INTRODUCTION}

Recently, several investigations have been concentrated on antenatal diagnosis using DNA analysis of sex determination (Gosden et al., 1984a, b; Lau et al., 1984; Nagai et al., 1984, 1986). Such an antenatal diagnostic method for sexlinked disorders such as Duchenne muscular dystrophy, hemophilia, and LeschNyhan syndrome is important, because if fetal sex is determined a female, further testing is unnecessary. However, Y-chromosome-specific DNA probe have been being applied for not only fetal sex determination but also for the studies on structural analysis and clinical diagnosis of Y-chromosome and its variants (Cooke et al., 1982; Gänshirt and Pawlowitzki, 1984; Lau, 1985; Nakahori and Nakagome, 1986). In addition, the use of Y-specific DNA-probes for fetal sex determination can provide several advantages over conventional karyotypic analysis. In order to determine fetal sex as early as possible, cytogenetic techniques by culturing amniotic fluid cells usually will consume more time and contamination with maternal tissue sometimes gives little or no effective results. Fetal sex determination method by the use of $\mathrm{Y}$-specific DNA probes shortens the time required for analysis, and DNA extraction can be avoided if dot hybridization is applied. In this study, fetal sex determination using a male-specific new DNA probe was identified, thereby uncultured samples such as amniotic fluid cells, placenta, and blood (or lymphocytes) also can be applied.

\section{MATERIALS AND METHODS}

Enzymes and chemicals. Restriction enzymes were purchased from Takara Shuzo Co. and Nippongene Co. (Japan) and were used under conditions recommended by the suppliers. Radiochemicals were obtained from Amersham or New England Nuclear (England).

$D N A$ cloning. The $3.5 \mathrm{~kb}$ fragments obtained from HaelII-digested human genomic-DNA of a male was separated on a $0.8 \%$ agarose gel, and was recovered by electroelution (Maniatis et al., 1982). Isolated DNA was labeled with $\left[\alpha^{-32} \mathrm{P}\right]-$ dCTP by nick-translation (Kelly et al., 1970) and was used as a probe for screening human genomic libraries (constructed with $\lambda$-Charon $4 \mathrm{~A}$ and $E c o$ RI fragments by T. Maniatis). Although three positive plaques could be isolated from about four thousands ones, one of them had $5.65 \mathrm{~kb} \mathrm{HaeIII}$ fragment which could specifically hybridize with human Y-specific $3.5 \mathrm{~kb}$ repetitive-DNA. The $5.65 \mathrm{~kb}$ DNA was subcloned by ligating into SmaI site of plasmid pUC19. As a result, it was designated as $5.7 \mathrm{~kb}$ pKY-1. The previously cloned Y-specific $3.5 \mathrm{~kb}$ DNA (pHY-10) (Nakahori and Nakagome, 1986) was also used for human Y-specific referenceDNA-probe.

DNA preparation from fetal specimens. DNA from placenta was extracted after isolation of nuclei by a modified method of Gross-Bellard et al. (1973). DNA 
isolated from chorionic villi, lymphocyte or whole blood can be prepared by essentially similar method as described above and plasmid was prepared by alkaline procedure (Birnoboim and Doly, 1979).

Restriction enzyme digestion and agarose slab-gel electrophoresis. The isolated human genomic DNAs were digested to completion with a variety of restriction endonucleases using appropriate buffers (Takara Inc., Japan). In most reactions, 1 to 2 units of enzymes per $\mu \mathrm{g}$ of DNA were used and digestion was carried out at a concentration of less than $200 \mu \mathrm{g} / \mathrm{ml}$ for 1 to $10 \mathrm{hr}$ at $37^{\circ} \mathrm{C}$.

After extraction with phenol, restriction products were subjected to electrophoresis on $0.8 \%(\mathrm{w} / \mathrm{v})$ agarose slab gel with a $\lambda$-HindIII marker. After electrophoresis, restriction patterns of DNA were visualized by staining with ethidium bromide $(0.5 \mu \mathrm{g} / \mathrm{ml})$. The migration during electrophoresis of $\lambda$-HindIII DNA was measured as molecular weight reference.

Blotting and hybridization procedures. Fragments of DNA were transfered from the agarose gel to nitrocellulose sheets and hybridized to nick-translated restriction fragments according to the methods of Southern (1975). Prior to hybridization, the filters were successively treated at $65^{\circ} \mathrm{C}$ with $10 \mathrm{ml}$ of $3 \times$ SSC for 30 min, Denhard's solution $[0.02 \%(\mathrm{w} / \mathrm{v})$ bovine serum albumin, $0.02 \%(\mathrm{w} / \mathrm{v})$ polyvinylpyrolidone and $0.02 \%(\mathrm{w} / \mathrm{v})$ Ficoll (Pharmacia Fine Chemicals)] in $3 \times \mathrm{SSC}$ for $60 \mathrm{~min}$, and were rinsed with $50 \mathrm{ml}$ of the Denhard's in NEST buffer $(1 \mathrm{M} \mathrm{NaCl}$, $10 \mathrm{~mm}$ EDTA, $0.1 \% \mathrm{SDSa}, 50 \mathrm{~mm}$ Tris- $\mathrm{HCl}, \mathrm{pH}$ 7.6). After pretreatment, hybridization was carried out in NEST buffer containing denatured herring sperm, human female DNA $(10 \mu \mathrm{g} / \mathrm{ml})$ and radioactive probe $\left(10^{7}\right.$ to $10^{8} \mathrm{cts} / \mathrm{min}$ per $\mu \mathrm{g}$ DNA) at $65^{\circ} \mathrm{C}$ for $10 \mathrm{hr}$. Then, the filters were washed twice with $0.3 \times$ SSC-containing $0.1 \% \mathrm{SDSa}$ for $30 \mathrm{~min}$ at $65^{\circ} \mathrm{C}$.

Autoradiography was performed on Fuji-RX film with Dupont Lightning Plus intensifier for 1 to $24 \mathrm{hr}$.

\section{RESULTS}

\section{DNA cloning}

Three positive plaques were found in about 4 thousands ones by screening human genomic library. One of positive plaques had $5.65 \mathrm{~kb}$ HaeIII fragments which were specifically hybridized with Y-chromosome specific-3.5 kb repetitiveDNA. Since it was subcloned by plasmid pUC19, this was designated as $5.7 \mathrm{~kb}$ pKY-1. Thus, cloned pKY-1 DNA which was analyzed on its restriction site map and was also applied for fetal sex-determination probe as described in following sections.

\section{Analysis for restriction site map of $p K Y-1$}

A restriction site map of $\mathrm{pKY}-1$ was generated by single and double digests of the DNA with various restriction enzymes. The digests were analyzed by Southern hybridization after $0.8 \%$ agarose slab gel electrophoresis. After hybridiza- 
tion by employing both probes of $\mathrm{pKY}-1$ and $\mathrm{pHY}-10$, completely identical patterns were demonstrated (Fig. 1). As shown in Fig. 1, digestion of pKY-1 with a variety of the enzymes clarified that the cloned phage DNA had $16.4 \mathrm{~kb}$ fragment as an insert containing the sites for the following enzymes: one EcoRI, two BamHI, and two HaeIII. Human Y-specific $3.5 \mathrm{~kb}$ DNA was specifically hybridized only with the $5.7 \mathrm{~kb}$ fragments (pKY-1) isolated by HaelII digestion of insert from the phage DNA. Furthermore, the $5.7 \mathrm{~kb}$ pKY-1 DNA was cloven into $0.55,2.40$ and $2.70 \mathrm{~kb}$ fragments by double digestion with $\mathrm{BamHI}$ and $\mathrm{ClaI}$ (Nagai et al., unpublished). The restriction site map was consequently summarized from above described results (Fig. 2). The $3.5 \mathrm{~kb}$ repeated units however, were not liberated from pKY-1 even by EcoRI and HaeIII as well as their double

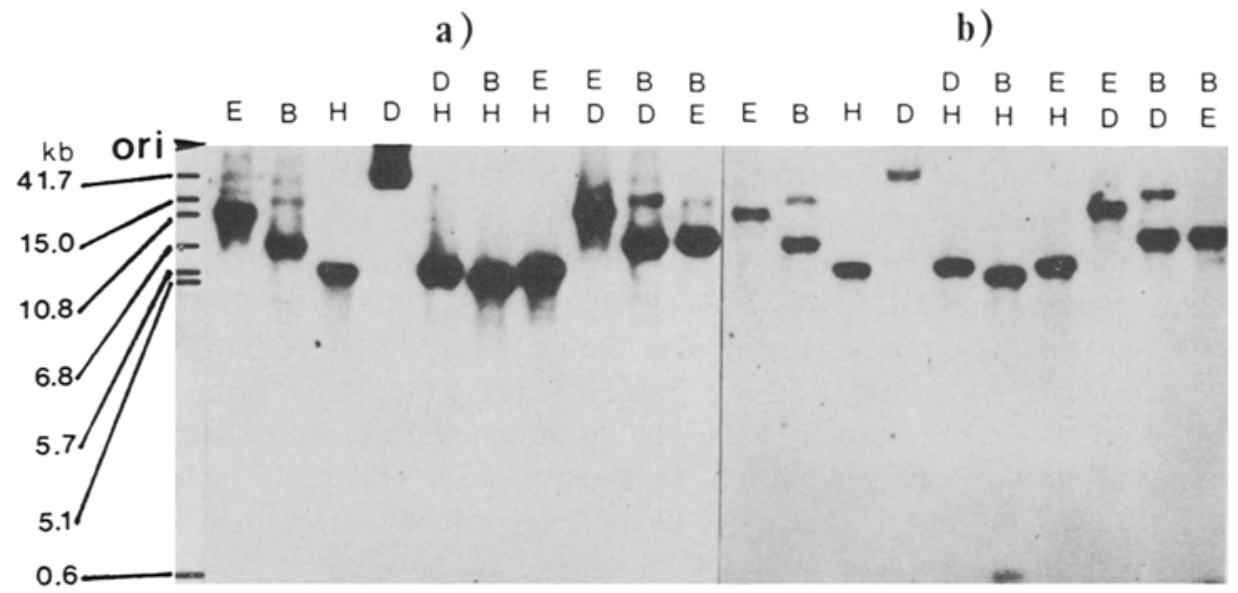

Fig. 1. Restriction endonuclease digestion of newly cloned DNA. Five $\mu \mathrm{g}$ of phage DNA were digested by a variety of restriction endonucleases and were analyzed on $0.8 \%$ agarose slab gel-electrophoresis. Southern hybridizations were carried out as described in MATERIALS AND METHODS. a) $5.7 \mathrm{~kb}$ (pKY-1) probe. b) $3.5 \mathrm{~kb}(\mathrm{pHY}-10)$ probe. Abbreviations of restriction endonucleases: E, EcoRI; B, BamHI; D, HindIII; H, HaeIII.

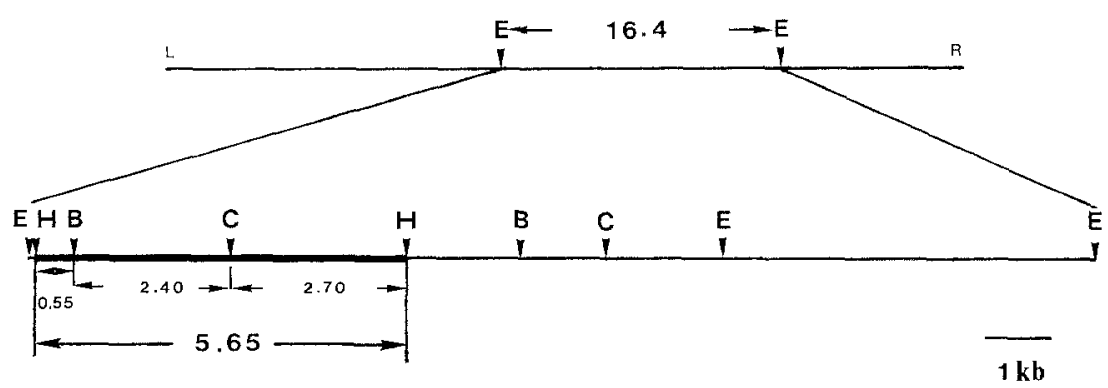

Fig. 2. The restriction site map of newly cloned DNA. The restriction sites of enzymes were indicated by similar abbreviations as described in Fig. 1, except ClaI was shown by $\mathrm{C}$. 
digestion. To confirm the hybridizability of $\mathrm{pKY}-1$ with Y-specific $3.5 \mathrm{~kb}$ DNA and subsequent applicability for fetal diagnosis probe, following experiments were undertaken.

\section{Fetal sex determination by employing $5.7 \mathrm{~kb}$ DNA probe}

For fetal sex determination, $5 \mu \mathrm{g}$ human fetal DNA-specimens (A, B and C) were analyzed with reference to human male genomic DNA by Southern blot hybridization (Fig. 3). The hybridizabilities of pKY-1 as a DNA probe with $\mathrm{Y}$ specific $3.5 \mathrm{~kb}$ DNA observed in the specimen of A and male reference DNA were demonstrated in essentially identical patterns as that of $\mathrm{pHY}-10$. Since no positive signals were detected in both DNA specimens of B and C, they were identified as females. In addition, pKY-1 did not hybridize with another human Y-specific 2.1

a)

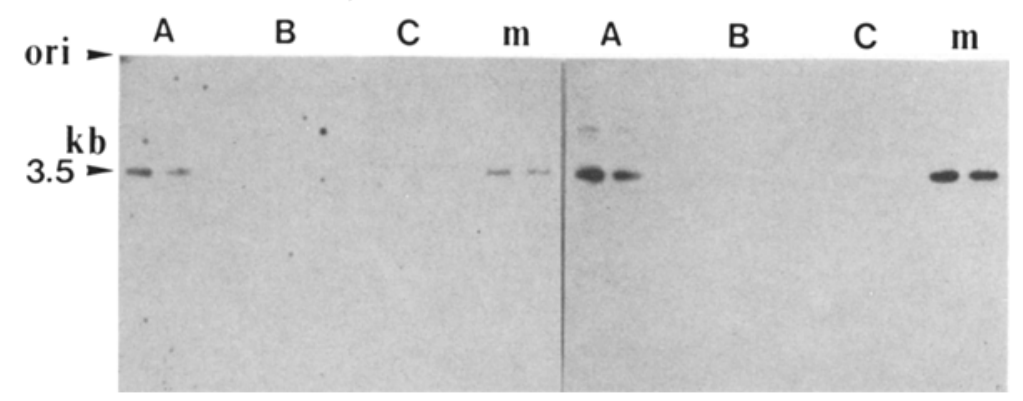

Fig. 3. The fetal sex determination by Southern hybridization. Five $\mu \mathrm{g}$ human placental DNA was digested completely with HaeIII and were analyzed by Southern hybridization as described in MATERIALS AND METHODS. A, B, and C are placental DNA specimens. $\mathrm{m}$, a male reference-DNA. a) $5.7 \mathrm{~kb}$ (pKY-1) probe. b) $3.5 \mathrm{~kb}(\mathrm{pHY}-10)$ probe.

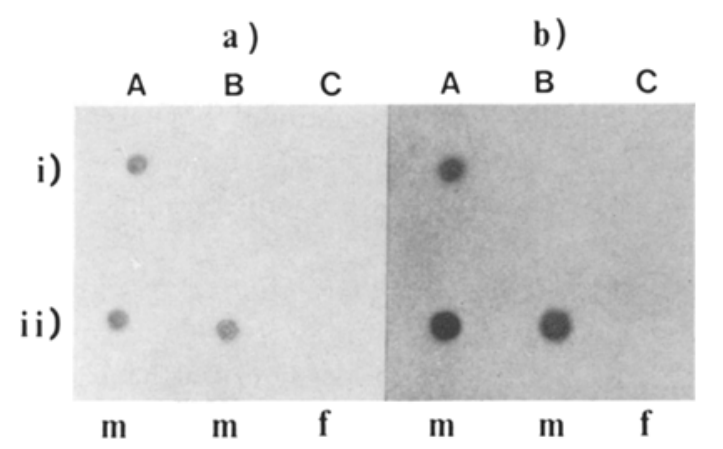

Fig. 4. The fetal sex determination by dot blot hybridization. Two $\mu \mathrm{g}$ placental DNA treated with $0.2 \mathrm{~N} \mathrm{NaOH}$ in $0.6 \mathrm{M} \mathrm{NaCl}$ were blotted on to nitrocellulose filters, and were neutralized with $0.5 \mathrm{M}$ Tris- $\mathrm{HCl}(\mathrm{pH} \mathrm{7.6)}-0.6 \mathrm{M} \mathrm{NaCl}$ and $2 \times \mathrm{SSC}$. The hybridizations were carried out as described in Fig. 3. i) A, B and C are fetal DNA specimens as arranged in Fig. 3. ii) Reference DNA: m, male; f, female. a) $5.7 \mathrm{~kb}(\mathrm{pKY}-1)$ probe. b) $3.5 \mathrm{~kb}$ (pHY-10) probe. 
$\mathrm{kb}$ DNA known to be unable to cross-hybridize with the $3.5 \mathrm{~kb}$ DNA. These results indicate that a male specific signal in human genomic DNA can be discriminated by employing a more rapid test. Similar DNA specimens as arranged in Fig. 3 were applicable to sex determination by dot blot hybridization (Fig. 4). The hybridizabilities for both DNA probes of $\mathrm{pKY}-1$ and $\mathrm{pHY}-10$ were distinctly demonstrated as identical male specific signals. This was also confirmed by using tissue homogenates specimens without extracting DNA (Nagai et al., unpublished data). From the autoradiograms obtained from Southern and dot hybridization using ${ }^{32}$ P-labeled $5.7 \mathrm{~kb}$ DNA as a probe, its copy number in human genome was deduced as about a dozen or more. However, good hybridization and its specificity with Y-chromosome-specific $3.5 \mathrm{~kb}$ repetitive-DNA will be effective for human sex determination. In addition, we could confirm the human gene specificity by evidence that the pKY-1 DNA probe didn't show cross-hybridization with male and female genomic DNA of other eukaryotes such as monkey, rat, mice, chicken, rana and masou (Nagai et al., manuscript in preparation).

\section{DISCUSSION}

In this study, the human male-specific $5.7 \mathrm{~kb}$ DNA (pKY-1) was specifically hybridized with $\mathrm{Y}$-specific $3.5 \mathrm{~kb}$ repetitive-DNA. From this result, the pKY-1 must be a member of Y-chromosome-specific repetitive-DNA family. This was supported by $\mathrm{Ag}^{+} \mathrm{Cs}_{2} \mathrm{SO}_{4}$ equilibrium centrifugation that both buoyant density of pKY-1 and $3.5 \mathrm{~kb}$ DNA had relatively coincided at $1.535 \mathrm{~g} / \mathrm{cm}^{3}$ (Nagai et al., unpublished data). These results suggest that both DNA has relatively common base composition and/or the sequences in their fragments. Therefore, by labeling the pKY-1 with $\left[\alpha^{-32} \mathrm{P}\right] \mathrm{dCTP}$, we have tested a possibility to apply a sex determination probe for fetal derived DNA materials. Although the $\mathrm{pKY}-1$ gave reasonable results as DNA probe for human sex determination, it took a slightly longer exposure time since its copy number was lower than those of $3.5 \mathrm{~kb}$ DNA. On the other hand, good male specificity of the $\mathrm{pKY}-1$ probe simplifies the test procedure and offers several advantages over conventional karyotypic analysis as those of other probes (Gosden et al., 1984a, b; and Lau et al., 1984). If dot hybridization is applied to avoid DNA-extraction, only small amounts of fetal DNA materials are required.

However, during the cloning, characterization of $5.7 \mathrm{~kb}$ DNA and subsequent its application for fetal sex determination probe, a few interesting problems have arisen that HaeIII, EcoRI and their double digestion have produced no Y-specific $3.5 \mathrm{~kb}$ fragments. On the other hand, BamHI-digestion liberated the 0.55 and 5.10 $\mathrm{kb}$ from $\mathrm{pKY}-1$ and latter fragments was cloven into 2.40 and $2.70 \mathrm{~kb}$ by ClaIdigestion. All these fragments however, had essentially similar hybridizability with Y-specific $3.5 \mathrm{~kb}$ DNA (Nagai et al, unpublished data). In addition, human gene specificity was confirmed by evidence that $\mathrm{pKY}-1$ did not cross-hybridize with other animal genomic DNA. This suggests that the sequence and its repetition 
of pKY-1 is essentially different from other eukaryotic genome-DNA such as monkey, rats, mice, chicken, rana and masou. The origin, biological role of pKY-1 and its relationship with previously cloned repetitive $3.5 \mathrm{~kb}$ DNA from human Y-chromosome should be further clarified. These results confirm that a male specific $5.7 \mathrm{~kb}$ DNA ( $\mathrm{pKY}-1$ ) could be provided as a new probe not only for human fetal sex-determination but also for structural study of $\mathrm{Y}$-chromosome with its variants and specific repetitive DNA.

Acknowledgments The authors wish to thank to Dr. T. Maniatis (Harvard University, U.S.A.) for kindly offering of human genomic libraries (constructed by $\lambda$-Charon 4A) and Dr. M. Mukaida (Department of Forensic Medicine, University of Tokyo) for kind donation of animal genomic DNA.

\section{REFERENCES}

Birnboim, H.C. and Doly, J. 1979. Rapid alkaline extraction procedure for screening recombinant plasmid DNA. Nucleic Acid Res. 7: 1513-1523.

Cooke, H.J., Schmidtke, J. and Gosden, J.R. 1982. Characterization of human Y-chromosome repeated sequence and related sequences in higher primates. Chromosoma 87: 491-502.

Gänshirt, D. and Pawlowitzki, I.H. 1984. HaeIII restriction of DNA from three cases with non fluorescent Y-chromosomes (45XO/46XYnf). Hum. Genet. 67: 241-244.

Gosden, J.R., Gosden, C.M., Christie, S. and Morsman, J.M. 1984a. Rapid fetal sex determination in first trimester prenatal diagnosis by dot hybridization. Lancet I: $540-541$.

Gosden, J.R., Gosden, C.M., Christie, S., Cooke, H.J., Morsman, J.M. and Rodeck, C.H. 1984b. The use of cloned Y-chromosome-specific DNA probes for fetal sex-determination in first trimester prenatal diagnosis. Hum. Genet. 66: 347-351.

Gross-Bellard, M., Oudet, P. and Chambon, P. 1973. Isolation of high-molecular-weight DNA from mammalian cells. Eur. J. Biochem. 36: 32-38.

Kelly, R.B., Cozzarelli, N.R., Deustcher, M.P., Lehman, I.R. and Konberg, A. 1970. Enzymatic synthesis of deoxyribonucleic acid (labelling of DNA with ${ }^{32} \mathrm{P}$ by nick translation). J. Biol. Chem. 245: 39-45.

Lau, Y.F., Huang, J.C., Dozy, A.M. and Kan, Y.W. 1984. A rapid screening test for antenatal sex determination. Lancet II: 14-16.

Lau, Y.F. 1985. Detection of Y-specific repeat sequences in normal and variant human chromosomes using in situ hybridization with biotinylated probes. Cytogenet Cell Genet. 39: 184187.

Maniatis, T., Fritsch, E.F. and Sambrook, J. 1982. Molecular Cloning-A Laboratory Manual. Cold Spring Harber Laboratory, Cold Spring Harbor, New York, pp. 164-165.

Nagai, K., Koike, S., Kominami, R., Muramatsu, M., Soma, H. and Yanagisawa, I. 1984. Cloning of human Y chromosome specific DNA. The 7th Meeting of the Molecular Biology Society of Japan (abstract): 19.

Nagai, K., Kominami, R. and Yanagisawa, I. 1986. The characterization of human Y-chromosome-specific cloned $5.7 \mathrm{~kb}$ DNA. Biol. Chem. Hoppe-Seyler, 367 (Supple.): 163.

Nakahori, Y. Mitani, K., Yamada, M. and Nakagome, Y. 1986. A human Y-chromosome specific repeated DNA family (DYZ1) consist of a tandem array of pentanucleotides. Nucleic Acids Res. 14: 7569-7580.

Southern, E.M. 1975. Detection of specific sequences among DNA fragments separated by gel electrophoresis. J. Mol. Biol. 98: 503-517. 